\title{
Australian Journal of

\section{Rehydration of dry corn grain as an alternative for conservation purposes}

\author{
Mircéia Angele Mombach ${ }^{1^{*}}$, Dalton Henrique Pereira ${ }^{2}$, Douglas do Santos Pina ${ }^{3}$, Odilon Gomes Pereira ${ }^{4}$, \\ Dheyme Cristina Bolson ${ }^{5}$, Bruno Carneiro e Pedreira ${ }^{6}$
}

\author{
${ }^{1}$ Universidade Federal de Mato Grosso - FAAZ - Av. Fernando Côrrea, 78060-900 -Cuiabá, MT, Brazil \\ ${ }^{2}$ Universidade Federal de Mato Grosso - ICAA -Av. Alexandre Ferronato, 78557-970 - Sinop, MT, Brazil \\ ${ }^{3}$ Universidade Federal da Bahia, Av. Ademar de Barros, 40170-110 - Salvador, BA, Brazil \\ ${ }^{4}$ Universidade Federal de Viçosa, Av. Peter Henry Rolfs, 36570-000 - Viçosa, MG, Brazil \\ ${ }^{5}$ Universidade Estadual de Maringá, Av. Colombo, 87020-900 - Maringá, PR, Brazil \\ ${ }^{6}$ Embrapa Agrossilvipastoril, Rod. Pioneiros, 78550-970 - Sinop, MT, Brazil
}

\section{*Corresponding author: mirceia@zootecnista.com.br}

\begin{abstract}
Glycerol, the main constituent of crude glycerin, has high energy efficiency and may provide energy to microorganisms in silage. Therefore, we evaluated the effect of including crude glycerin (CG) and a bacterial inoculant on the chemical composition, losses, fermentation profile, microbial population and aerobic stability of rehydrated corn grain silage. The dry corn grain $\left(800 \mathrm{~g} \mathrm{~kg}^{-1} \mathrm{dry}\right.$ matter (DM)) was milled to $5 \mathrm{~mm}$ and rehydrated with water and glycerin to achieve $32.5 \%$ moisture content. Crude glycerin was added at $0,75,150$ and $225 \mathrm{~g} \mathrm{~kg}^{-1}$ (natural matter (NM)), with or without bacterial inoculant. The experiment was randomized, and included three replicates in a factorial scheme, with or without bacterial inoculant, four crude glycerin levels and five fermentation periods. CG inclusion in silage decreased the nitrogenous and fibrous fractions, gas losses, DM recovery, and microbial growth. However, CG addition increased effluent and total DM losses. Treatment with 0 and $75 \mathrm{~g} \mathrm{~kg}^{-1} \mathrm{CG}(\mathrm{NM})$ resulted in lower $\mathrm{pH}$ (4.6; $4.28)$ at 64 days of fermentation. Silage without CG remained stable to oxygen after 12 days. The bacterial inoculant did not influence the variables analyzed. We conclude that CG inclusion, bacterial inoculant or a combination of these additives is not recommended for this type of material. Nevertheless, rehydration with water ( $\left.125 \mathrm{~g} \mathrm{~kg}^{-1} \mathrm{DM}\right)$ is an alternative for storage of corn grain silage through the ensiling process.
\end{abstract}

Keywords: glycerol, biofuel, Lactobacillus, silage.

Abbreviation: $A D F$ _ acid detergent fiber, $C F U_{-}$colony forming unit, $C_{-}$crude glycerin, $C_{\text {_ }}$ crude protein, $D M$ _dry matter, $E E_{-}$ ether extract, EL_ effluent losses, ENT_ enterobacteria, FP_ fermentation period, GL_ gas losses, LAB_ lactic acid bacteria, MM_mineral matter, NDF_neutral detergent fiber, NFC_non-fibrous carbohydrates, $\mathrm{NH}_{3}-\mathrm{N}_{-}$ammoniacal nitrogen, $\mathrm{NM}$ _natural matter, TA_titratable acidity, TC_ total carbohydrates, TDML_total dry matter losses, TDMR_ total dry matter recovery, $\bar{T} N_{-}$total nitrogen.

\section{Introduction}

Due to its vast territorial size, large amounts of agricultural land and climate diversity, Brazil is one of the countries with the largest cereal production, especially corn grain. However, due to a lack of infrastructure to store these grains, the country faces numerous storage-related problems, which increases losses and consequently production costs.

As much of the corn produced in Brazil is intended for animal feed, one alternative to minimize the storage problem during the harvest would be to utilize the ensiling process, after grinding and rehydrating the material to the proper moisture content for this method of preservation. However, the literature is scarce in studies evaluating the rehydration of cereals, as corn grain.

In addition, rehydrated corn grain, can be a form grain storage alternative, too improve the digestibility of corn
(Ferraretto et al., 2014). Rehydration breaks down the hydrophobic starch-protein matrix surrounding starch granules during ensiling (McAllister et al., 1993; Hoffman et al., 2011), which allows better utilization of nutrients by ruminants (McAllister et al., 1993).

Various additives, including bacterial cultures, can be used to improve the nutritive value of silage. Nevertheless, data from studies evaluating the use of this type of additive are quite controversial (Muck 2004; Gimenes et al., 2006; Zopollatto et al., 2009; Basso et al., 2012; Santos et al., 2013; Lara et al., 2016; Mohammadzadeh et al., 2016).

Although bacterial additives can favor dry matter recovery from ensiled material (Kung Júnior et al., 2003), co-products of the biofuel industry may also be used as alternative additives to improve the fermentation process (Van Cleef et al., 2012; Martins et al., 2014; Gomes et al., 2015). 
Glycerol, which is the main constituent of crude glycerin, is widely used to feed ruminants (Van Cleef et al., 2014; Carvalho et al., 2015) due to high energy efficiency and having been intensively tested as an ingredient in diets for other animals (Oliveira et al., 2014; Gonçalvez et al., 2015; Arif et al., 2017). Moreover, this feed additive can be used as an energy source by microorganisms in the silage by replacing rapidly fermentable carbohydrates (Gomes et al., 2015). However, there is no information in the literature regarding the use of glycerin in the ensiling process. In addition, there are no studies detailing the fermentative characteristics, losses and microbial composition of rehydrated corn grain.

This study aimed to evaluate the chemical composition, losses, fermentation profile, microbial populations and aerobic stability in coarsely milled corn grain silage rehydrated with water and containing crude glycerin and bacterial inoculant.

\section{Results}

\section{Chemical composition}

Most of the variables analyzed for chemical composition were influenced by the increase in CG levels after 64 days of ensilage (Table 1). The crude protein (CP), neutral detergent fiber (NDF) and acid detergent fiber (ADF) content was reduced by $0.23,0.08$ and $0.04 \mathrm{~g} \mathrm{~kg}^{-1} \mathrm{DM}$, respectively, for each $1 \mathrm{~g} \mathrm{~kg}^{-1} \mathrm{CG}$ addition (NM). However, the silage with the highest CG levels had the highest total carbohydrates (TC) and non-fibrous carbohydrates (NFC) values, at 858 and $779.7 \mathrm{~g} \mathrm{~kg}^{-1}$, respectively.

The bacterial inoculant alone did not influence any of the analyzed chemical composition variables. However, there was an interaction effect between this additive and the crude glycerin for DM, mineral matter (MM), and ether extract (EE). The DM and MM variables increased linearly with CG addition (Table 2), but increased levels of this additive reduced the $\mathrm{EE}$ content by $0.18 \mathrm{~g} \mathrm{~kg}^{-1}$ (DM) for each $1 \mathrm{~g} \mathrm{~kg}^{-1} \mathrm{CG}(\mathrm{NM})$ added to the silage.

\section{Losses}

The fermentation profile variables were only influenced by CG inclusion. Effluent (EL) and total dry matter (TDML) losses increased with $C G$ addition. The greatest loss was observed after the addition of $225 \mathrm{~g} \mathrm{~kg}^{-1}$ CG (NM) (Table 3). However, gas losses (GL) were reduced approximately $68 \%$ in the treatment with greater CG inclusion relative to the silage without CG. Total dry matter recovery (TDMR) was also reduced after CG inclusion with a lowest value at 64 days of fermentation for the treatment with $225 \mathrm{~g} \mathrm{~kg}^{-1} \mathrm{CG}$ (NM).

\section{Fermentation profile and microbial population}

There was an interaction effect between the fermentation period (FP) and CG addition for all fermentation profile variables analyzed. The $\mathrm{pH}$ decreased throughout the FP independently of the treatment, with the lowest values observed for 0 and $75 \mathrm{~g} \mathrm{~kg}^{-1}$ (NM) CG inclusion (Fig. 1). However, the titratable acidity (TA) and ammoniacal nitrogen $\left(\mathrm{NH}_{3}-\mathrm{N}-\mathrm{g} \mathrm{kg}^{-1}\right.$ total nitrogen) content was higher for these treatments and greatest on the $64^{\text {th }}$ day of fermentation.

Yeasts and molds were the only groups of microorganisms that did not affect the interaction between the bacterial inoculant, $C G$, and $F P$, but no regression model was adjusted for these variables. For $L A B$ and ENT, there was an interaction between the bacterial inoculant, FP, and CG. The bacterial inoculant was not effective in increasing the lactic acid bacteria (LAB) and enterobacteria populations within each CG treatment (Table 4). However, CG inclusion reduced the $L A B$ population, with the lowest values observed at 150 and $225 \mathrm{~g} \mathrm{~kg}^{-1}$ levels (NM). Following treatment with 0 and $75 \mathrm{~g} \mathrm{~kg}^{-1} \mathrm{CG}$, this population remained high until the $16^{\text {th }}$ fermentation day and decreased thereafter. For the silage with 150 and $225 \mathrm{~g} \mathrm{~kg}^{-1}$ CG inclusion (NM), the LAB reductions began to occur from the $8^{\text {th }}$ fermentation day, and there was an absence of CFU after the $32^{\text {nd }}$ fermentation day.

The enterobacteria also decreased upon CG inclusion, but the reduction effect was lower compared to LAB. However, even for the treatments with lower CG levels $\left(0\right.$ and $75 \mathrm{~g} \mathrm{~kg}^{-1}$ $\mathrm{NM})$, the reduction in enterobacteria occurred after the $8^{\text {th }}$ fermentation day, with an absence of CFUs for all CG levels by the end of the fermentation period $\left(64^{\text {th }}\right.$ day).

Only the silage without CG maintained aerobic stability after 12 days (Fig. 2). The treatments with 75 and $150 \mathrm{~g} \mathrm{~kg}^{-1}$ CG (NM) without inoculant had the lowest stabilities when exposed to oxygen, being stable for 72 and 78 hours, respectively. However, all treatments containing CG demonstrated a breakdown of stability after exposure to oxygen.

\section{Discussion}

Crude glycerin presents low levels of nitrogenous and fibrous fractions (Dias et al., 2014). Therefore, the inclusion of CG in silage reduces the CP, NDF, and ADF levels and consequently increases the carbohydrate fraction, as these values are estimated using equations influenced by the fibrous fractions (NDF and ADF). The same effect was observed for the CP, NDF, FDA, TC, and NFC values in studies performed by Martins et al. (2014) and Gomes et al. (2015) after the inclusion of different quantities of glycerol (the main constituent of CG) in corn silage.

The increase in DM content after CG addition occurred due to the increase in effluent loss (Table 3 ). Despite the increase in DM content, the values obtained in this experiment were between 25 and $35 \%$ DM, as recommended by McDonald (1991) to obtain desirable conditions for fermentation and inhibition of Clostridium. The high mineral matter content observed in the silage with higher CG levels was caused by high mineral matter content in the CG $\left(\sim 7 \mathrm{~g} \mathrm{~kg}^{-1}\right.$ DM). Numerous studies have demonstrated the high mineral content of CG (Oliveira et al., 2013; Simas et al., 2010; Thompson and $\mathrm{He}, 2006)$.

There is great variability in the percentage and types of lipids in CG as a function of the type of catalysis used for biodiesel production (Oliveira et al., 2013; Simas et al., 2010). This may have contributed to the reductions in EE content in the silage with added CG.

The greatest effluent losses observed in the silage with the higher CG content are related to the physical form of this additive. As it is a viscous fluid, CG has the potential to flow 
Table 1. Chemical composition of rehydrated corn grain silage with bacterial inoculant and crude glycerin inclusion at 64 days of fermentation.

\begin{tabular}{|c|c|c|c|c|c|c|c|c|c|c|}
\hline \multirow[t]{2}{*}{ Variable } & \multicolumn{2}{|c|}{ Bacterial Inoculant } & \multicolumn{4}{|c|}{$\begin{array}{c}\text { Crude glycerin } \\
\left(\mathrm{g} \mathrm{kg}^{-1} \mathrm{NM}\right)\end{array}$} & \multicolumn{3}{|c|}{$P$-value } & \multirow[t]{2}{*}{ Eq } \\
\hline & Without & With & 0 & 75 & 150 & 225 & $\mathrm{I}$ & CG & $I \times C G$ & \\
\hline $\begin{array}{l}\text { Dry matter } \\
\left(\mathrm{g} \mathrm{kg}^{-1}\right)\end{array}$ & 677.8 & 682.2 & 663.6 & 671.3 & 678.5 & 706.1 & $*$ & $* *$ & $* *$ & -- \\
\hline Mineral matter & 22.4 & 22.5 & 14.2 & 19.6 & 25.6 & 30.5 & ns & $* *$ & $* *$ & -- \\
\hline Crude protein & 75.6 & 75.2 & 93.5 & 78.4 & 67.5 & 62.2 & ns & $* *$ & ns & 1 \\
\hline Ethereal extract & 58.4 & 57.0 & 72.1 & 62.1 & 50.3 & 46.2 & ns & $* *$ & $* *$ & - \\
\hline Neutral detergent fiber & 120 & 121.8 & 148.0 & 137.0 & 115.3 & 83.3 & ns & $* *$ & ns & 2 \\
\hline Acid detergent fiber & 41.4 & 43.2 & 52.2 & 49.8 & 38.8 & 28.4 & ns & $* *$ & ns & 3 \\
\hline Total carbohydrate & 842.1 & 845.4 & 820.7 & 839.8 & 856.5 & 858 & ns & $* *$ & ns & 5 \\
\hline Non-fibrous carbohydrate & 724.7 & 724.3 & 684.2 & 702.8 & 741.2 & 779.7 & ns & $* *$ & ns & 6 \\
\hline
\end{tabular}

ns=not significant; ${ }^{*} \mathrm{P}<0.05 ;{ }^{* *} \mathrm{P}<0.01 ; \mathrm{NM}=$ natural matter; $\mathrm{I}=$ bacterial inoculant; $\mathrm{CG}=$ crude glycerin; I $\mathrm{CG}=$ interaction between bacterial inoculant (I) and crude glycerin (CG); Equation= 1: $\hat{Y}=93.57-0.24 * C G+0.0004 * C^{2}\left(R^{2}=0.99\right) ; 2: \hat{Y}=148-0.078 * C G-0.000{ }^{*} C^{2}{ }^{2}\left(R^{2}=0.95\right) ; 3: \hat{Y}=52.48-0.042 * C G-0.0003 * C^{2}\left(R^{2}=0.83\right) ; 4: \hat{Y}=93.69-0.0043 * C G-0.0008 * C G^{2}\left(R^{2}=0.88\right) ; 5: \hat{Y}=820.10+0.35 * C G-$ $0.0008 * \mathrm{CG}^{2}\left(\mathrm{R}^{2}=0.86\right) ; 6: \hat{Y}=673.74+0.37 * \mathrm{CG}+0.0005 * \mathrm{CG}^{2}\left(\mathrm{R}^{2}=0.97\right)$.
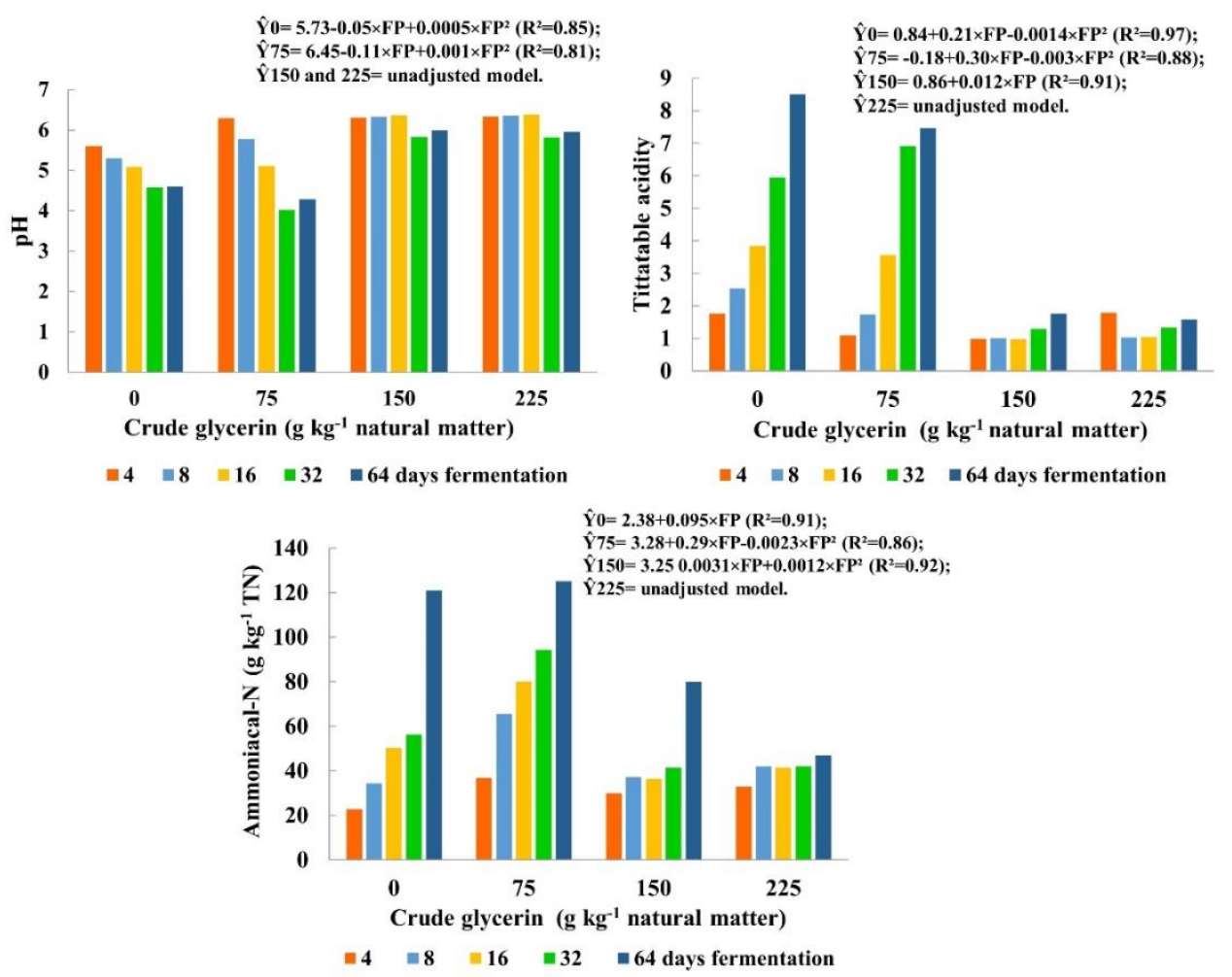

Fig 1. Fermentation profile of rehydrated corn grain silage with bacterial inoculant and crude glycerin throughout the fermentation period (FP).

Table 2. Contents of dry matter (DM), mineral matter ( $M M)$ and ether extract (EE) of rehydrated corn grain silage due to the presence of bacterial inoculant and crude glycerin inclusion at 64 days of fermentation.

\begin{tabular}{|c|c|c|c|c|c|c|}
\hline \multirow[t]{2}{*}{ Variable } & \multirow{2}{*}{$\begin{array}{l}\text { Bacterial } \\
\text { Inoculant }\end{array}$} & \multicolumn{4}{|c|}{ Crude glycerin $\left(\mathrm{g} \mathrm{kg}^{-1} \mathrm{NM}\right)$} & \multirow{2}{*}{ Equation } \\
\hline & & 0 & 75 & 150 & 225 & \\
\hline \multirow{2}{*}{$\mathrm{DM}\left(\mathrm{g} \mathrm{kg}^{-1}\right)$} & Without & $663.9 \mathrm{~A}$ & $673.7 A$ & $678.6 \mathrm{~A}$ & $694.3 B$ & 1 \\
\hline & With & $663.2 \mathrm{~A}$ & $668.9 A$ & $678.4 \mathrm{~A}$ & $717.9 \mathrm{~A}$ & 2 \\
\hline \multirow{2}{*}{$\mathrm{MM}\left(\mathrm{g} \mathrm{kg}^{-1} \mathrm{DM}\right)$} & Without & $15.0 \mathrm{~A}$ & $20.6 \mathrm{~A}$ & $25.4 \mathrm{~A}$ & $29.1 \mathrm{~B}$ & 3 \\
\hline & With & $13.4 \mathrm{~B}$ & $18.6 \mathrm{~B}$ & $25.9 A$ & $31.8 \mathrm{~A}$ & 4 \\
\hline \multirow{2}{*}{$\mathrm{EE}\left(\mathrm{g} \mathrm{kg}^{-1} \mathrm{DM}\right)$} & Without & 69.7B & $62.8 \mathrm{~A}$ & $51.2 \mathrm{~A}$ & $44.1 \mathrm{~B}$ & 5 \\
\hline & With & $74.5 \mathrm{~A}$ & $61.4 \mathrm{~A}$ & $49.5 \mathrm{~A}$ & $48.3 \mathrm{~A}$ & 6 \\
\hline
\end{tabular}

Means followed by equal letters column aren't different according to the predicted difference $(P<0.05)$. NM= natural matter; $D M=$ dry matter; Equation= 1: $\hat{Y}=664.72+0.071 \times C G\left(R^{2}=0.88\right) ; 2$ : $\hat{\mathrm{Y}}=664.56-0.10 \times \mathrm{CG}+0.0015 \times \mathrm{CG}^{2}\left(R^{2}=0.96\right) ; 3: \hat{Y}=14.94+0.082 \times C G\left(R^{2}=0.98\right) ; 4: \hat{Y}=13.29+0.077 \times C G\left(R^{2}=0.99\right) ; 5: \hat{Y}=70.42-0.12 \times C G\left(R^{2}=0.98\right) ; 6: \hat{Y}=74.92-0.24 \times C G+0.0005 \times C G^{2}\left(R^{2}=0.98\right)$. 


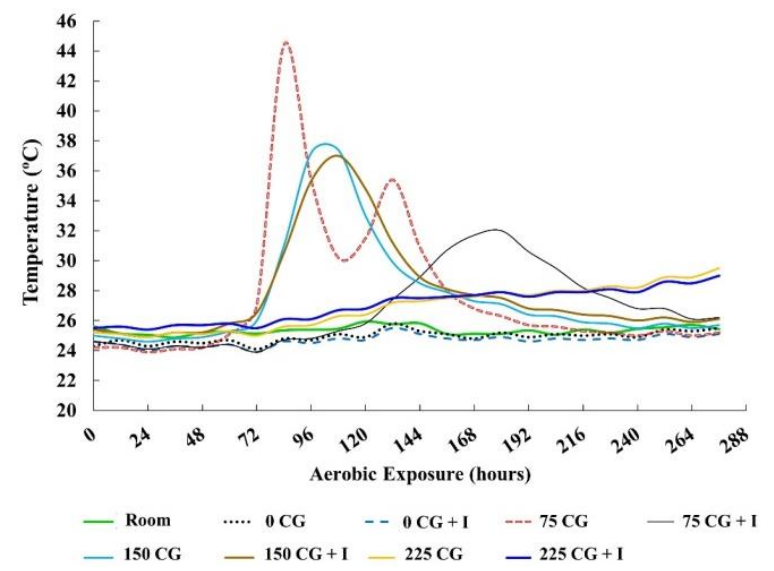

Fig 2. Changes in the temperature of corn grain silage with bacterial inoculant (I) and crude glycerin (CG) inclusion after aerobic exposure for 288 hours.

Table 3. Losses of rehydrated corn grain silage with bacterial inoculant and crude glycerin inclusion at 64 days of fermentation.

\begin{tabular}{|c|c|c|c|c|c|c|c|c|c|c|}
\hline \multirow{2}{*}{$\begin{array}{l}\text { Variable } \\
\left(\mathrm{g} \mathrm{kg}^{-1}\right)\end{array}$} & \multicolumn{2}{|c|}{ Bacterial Inoculant } & \multicolumn{4}{|c|}{ Crude glycerin $\left(\mathrm{g} \mathrm{kg}^{-1} \mathrm{NM}\right)$} & \multicolumn{3}{|c|}{$P$-value } & \multirow{2}{*}{ Eq. } \\
\hline & Without & With & 0 & 75 & 150 & 225 & 1 & CG & $\mathrm{I} \times \mathrm{CG}$ & \\
\hline EL (NM) & 25.80 & 26.53 & 1.34 & 10.44 & 40.42 & 52.47 & ns & $* *$ & $\mathrm{~ns}$ & 1 \\
\hline GL (DM) & 15.61 & 15.40 & 13.63 & 25.71 & 18.31 & 4.36 & ns & $* *$ & ns & 2 \\
\hline TDML (DM) & 40.58 & 41.88 & 13.29 & 35.68 & 58.18 & 57.77 & ns & $* *$ & ns & 3 \\
\hline TDMR DM) & 959.49 & 958.12 & 986.70 & 964.30 & 941.82 & 942.40 & ns & $* *$ & ns & 4 \\
\hline
\end{tabular}

$\mathrm{ns}=$ not significant; ${ }^{*} \mathrm{P}<0.05$; ${ }^{*} \mathrm{P}<0.01 ; \mathrm{EL}=$ effluent losses; $\mathrm{GL}=$ gas losses; TDML= total dry matter losses; TDMR= total dry matter recovery; NM= natural matter; DM= dry matter; $\mathrm{I}=$ bacterial inoculant; CG= crude glycerin; I x CG= interaction between inoculant (I) and crude glycerin (CG); Equation= 1: $\hat{Y}=-0.60+0.22 \times C G\left(R^{2}=0.93\right) ; 2$ : $\hat{Y}=14.28-0.21 \times C G-0.0012 \times C G^{2}\left(R^{2}=0.76\right) ; 3: \hat{Y}=$ $12.14+0.44 \times \mathrm{CG}-0.001 \times \mathrm{CG}^{2}\left(\mathrm{R}^{2}=0.90\right) ; 4: \hat{Y}=987.86-0.44 \times \mathrm{CG}+0.001 \times \mathrm{CG}^{2}\left(\mathrm{R}^{2}=0.90\right)$

Table 4. Number of lactic acid bacteria and enterobacteria in log colony-forming units per gram in the rehydrated corn grain silage with bacterial inoculant and crude glycerin throughout the fermentation period.

\begin{tabular}{|c|c|c|c|c|c|c|c|}
\hline \multirow{2}{*}{$\begin{array}{l}\text { Crude glycerin } \\
\left(\mathrm{g} \mathrm{kg}^{-1} \mathrm{NM}\right)\end{array}$} & \multirow{2}{*}{$\begin{array}{l}\text { Bacterial } \\
\text { Inoculant }\end{array}$} & \multicolumn{5}{|c|}{ Fermentation periods (days) } & \multirow{2}{*}{ Equation } \\
\hline & & 4 & 8 & 16 & 32 & 64 & \\
\hline \multirow{3}{*}{0} & & & $---L a$ & c acid ba & ria ----- & & 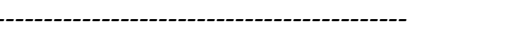 \\
\hline & Without & $7.18 \mathrm{~A}$ & $7.23 \mathrm{~A}$ & $7.13 \mathrm{~A}$ & $6.52 \mathrm{~A}$ & $5.46 \mathrm{~A}$ & $\hat{Y}=7.34-0.0016 \times F P\left(R^{2}=0.87\right)$ \\
\hline & With & $8.11 \mathrm{~A}$ & $7.32 \mathrm{~A}$ & $7.47 \mathrm{~A}$ & $7.22 \mathrm{~A}$ & $5.60 \mathrm{~A}$ & $\hat{Y}=7.82-0.0012 \times F P-0.0003 \times F P^{2}\left(R^{2}=0.83\right)$ \\
\hline \multirow{2}{*}{75} & Without & $6.43 A B$ & 7.77A & $6.98 \mathrm{~A}$ & $6.33 \mathrm{~A}$ & $5.40 \mathrm{~A}$ & $\hat{Y}=6.56+0.009 \times F P\left(R^{2}=0.97\right)$ \\
\hline & With & $7.87 \mathrm{~A}$ & $7.89 \mathrm{~A}$ & $7.69 \mathrm{~A}$ & $6.78 \mathrm{~A}$ & $5.89 \mathrm{~A}$ & $\hat{Y}=8.18-0.004 \times F P\left(R^{2}=0.92\right)$ \\
\hline \multirow{2}{*}{150} & Without & $5,2 \mathrm{~B}$ & $4.1 \mathrm{~B}$ & $2 \mathrm{~B}$ & OB & $\mathrm{OB}$ & UN \\
\hline & With & $6.67 A B$ & $6.36 \mathrm{AB}$ & $2.10 \mathrm{~B}$ & $O B$ & $\mathrm{OB}$ & $\hat{Y}=8.60-0.042 \times F P+0.0004 \times F P^{2}\left(R^{2}=0.79\right)$ \\
\hline \multirow{2}{*}{225} & Without & $4.53 \mathrm{~B}$ & $4.1 \mathrm{~B}$ & $\mathrm{OB}$ & $O B$ & $\mathrm{OB}$ & UN \\
\hline & With & $4.32 \mathrm{~B}$ & $5.00 \mathrm{~B}$ & $\mathrm{OB}$ & $\mathrm{OB}$ & $\mathrm{OB}$ & UN \\
\hline \multirow[b]{2}{*}{0} & Without & $6.48 \mathrm{~A}$ & $7.26 \mathrm{AB}$ & $\begin{array}{l}-- \text { Enter } \\
6.60 \mathrm{~A}\end{array}$ & $\begin{array}{c}\text { acteria - } \\
6.70 \mathrm{~A}\end{array}$ & 0 & $\hat{Y}=6.53+0.005 F P-0.0001 \times F^{2}\left(R^{2}=0.89\right)$ \\
\hline & With & $6.48 \mathrm{~A}$ & $7.21 \mathrm{AB}$ & $6.42 A B$ & $6.71 \mathrm{~A}$ & 0 & $\hat{Y}=6.11+0.011 \times F P-0.0003 \times F P^{2}\left(R^{2}=0.97\right)$ \\
\hline \multirow{2}{*}{75} & Without & $5.40 A B$ & $6.83 \mathrm{AB}$ & $6.20 \mathrm{AB}$ & $5.58 \mathrm{AB}$ & 0 & $\hat{Y}=5.56+0.009 \times F P-0.0003 \times F P^{2}\left(R^{2}=0.94\right)$ \\
\hline & With & $5.84 \mathrm{AB}$ & $7.71 \mathrm{~A}$ & $7.05 \mathrm{~A}$ & $6.05 \mathrm{AB}$ & 0 & $\hat{\mathrm{Y}}=6.20+0.01 \times \mathrm{FP}-0.0003 \times \mathrm{FP}^{2}\left(\mathrm{R}^{2}=0.96\right)$ \\
\hline \multirow{2}{*}{150} & Without & $4.97 \mathrm{~B}$ & $5.35 \mathrm{C}$ & $5.10 \mathrm{BC}$ & $1.83 \mathrm{C}$ & 0 & $\hat{\mathrm{Y}}=6.10-0.013 \times \mathrm{FP}\left(\mathrm{R}^{2}=0.71\right)$ \\
\hline & With & $5.39 A B$ & $5.91 B C$ & $4.73 C$ & $4.93 B$ & 0 & $\hat{Y}=5.30+0.004 \times F P-0.0002 \times F P^{2}\left(R^{2}=0.94\right)$ \\
\hline \multirow{2}{*}{225} & Without & $4.89 \mathrm{~B}$ & $5.39 \mathrm{C}$ & $2.28 \mathrm{D}$ & $2.63 C$ & 0 & $\hat{Y}=5.52-0.013 \times F P\left(R^{2}=0.63\right)$ \\
\hline & With & $5.51 \mathrm{AB}$ & $5.05 \mathrm{C}$ & 2.64D & $2,42 \mathrm{C}$ & 0 & $\hat{Y}=7.04-0.033 \times F P+0.0003 \times F P^{2}\left(R^{2}=0.86\right)$ \\
\hline
\end{tabular}

$\mathrm{NM}=$ natural matter; $\mathrm{FP}=$ fermentation period; $\mathrm{UN}=$ unadjusted model; Means followed by equal letters column aren't different according to the predicted difference $(\mathrm{P}<0.05)$

under compaction and pressure (Hu et al., 2012; Thompson and $\mathrm{He}, 2006)$. This may have contributed to the transport of liquid to the end of the silo increasing effluent losses. The increase in EL reflects the increase in LTDM and reductions in TDMR after CG inclusion. This occurs because EL and GL are taken into account for the LTDM calculation. Therefore, the losses are greater as the LTDM is higher. In turn, TDMR is inversely proportional to LTDM, decreasing as this loss increases.

GC inclusion may have had an antagonistic effect on the LAB and enterobacteria populations (Table 4). This antagonism likely contributed to the GL reductions, as the gasses produced during fermentation are generated by microbial degradation of sugars or by grain respiration during the 
initial stage of fermentation (Muck, 2010). Lara et al. (2016) with Bacillus subtilis and Lactobacillus plantarum relative to control silage or silage inoculated with $B$. subtilis alone, indicating that a larger population of microorganisms in the silage might contribute to increased GL during the fermentation process.

Bacterial inoculants increase DM recovery during the fermentation process due to the use of more efficient metabolic pathways, with lactic acid acting as the predominant final fermentation product (Muck, 2010). However, in this work, no significant inoculant-based differences were observed, due to reductions in the LAB population in response to increasing CG levels.

The lower $\mathrm{pH}$ and higher titratable acidity observed for silage with 0 and $75 \mathrm{~g} \mathrm{~kg}^{-1}$ CG (NM) (Fig. 1) probably occurred due to increased production of organic acids (lactic and acetic). This is evidenced by the greatest microbial populations in these treatments (Table 4), especially during the first days of fermentation, which is also consistent with the increases in $\mathrm{NH}_{3}-\mathrm{N}$ levels. The presence of microorganisms such as enterobacteria can stimulate proteolysis, increasing the ammoniacal compound levels in silage (Woolford, 1984). In addition, at $\mathrm{pH}>5.0$, the performance of proteases enhances $\mathrm{NH}_{3}-\mathrm{N}$ degradation (Berg et al., 2002). The most intense proteolysis occurring in the treatments with 0 and $75 \mathrm{~g} \mathrm{~kg}^{-1}$ CG (NM) was above the $10 \%$ limit considered suitable for silage. The reduction in the microorganism populations relative to the CG inclusion may have occurred due to the negative influence of some compound in this additive on microflora development. According to Pahlow et al. (2003), LAB species require oleic acid esters for growth. However, O'Leary (1962) affirm that gram-positive bacteria are more sensitive to all types of fatty acids than gram-negative bacteria, especially cis long-chain unsaturated fatty acids. The major fatty acids present in CG are oleic, linoleic, erucic palmitic and linolenic ( $\mathrm{Hu}$ et al., 2012; Thompson and He, 2006). Most of these fatty acids are unsaturated.

Other factors such as $\mathrm{pH}$ may contribute to reductions in microorganism numbers during the fermentation process. However, despite an increase in the production of organic acids, verified by the TA increase, the $\mathrm{pH}$ drop was not sufficient to inhibit $L A B$ and enterobacteria growth. This indicates that other factors influence the microbial population growth in rehydrated corn grain silage.

Higher quality silage with high concentrations of lactic acid and sugars are less stable when exposed to oxygen (Weinberg and Muck, 1996). Molds and yeasts, microorganisms responsible for aerobic deterioration, use lactic acid as a substrate for their development (Pahlow et al., 2003). Treatments with no CG, regardless of inoculant, maintained the largest populations of enterobacteria throughout fermentation (Table 4). This may have contributed to the greater aerobic stability of the silage, as acetic acid is the main sugar degradation product made by these microorganisms (McDonald et al., 1991). Acetic acid increases aerobic stability by inhibiting the growth of molds and yeasts (Danner et al., 2003).

\section{Materials and Methods}

\section{Localization}

observed higher $\mathrm{GL}$ values in corn silage inoculated The experiment was carried out at the Animal Nutrition Laboratory and Forage Institute of Agricultural and Environmental Sciences, Federal University of Mato Grosso, in Sinop, Mato Grosso, Brazil.

\section{Treatments}

The treatments included a combination of three factors, inoculation (with or without), crude glycerin (CG), and fermentation periods. The dry corn grain ( $\left.800 \mathrm{~g} \mathrm{~kg}^{-1} \mathrm{DM}\right)$, acquired from the region, was grossly disintegrated in a mill retrofitted with $5 \mathrm{~mm}$ mesh sieves. Prior to fermentation, the milled corn was rehydrated with water, and crude glycerin $\left(\mathrm{g} \mathrm{kg}^{-1}\right.$ of NM) added at ratios of 125:0, 125:75, $125: 150$, and $125: 225$ to maintain constant moisture content at $32.5 \%$ in all treatments. Increases in CG levels resulted in a reduction of corn percentage in the silage, thus maintaining moisture content.

The commercial inoculant used was KERA-SIL moist grain (Kera Animal Nutrition) consisting of Lactobacillus plantarum $\left(30 \times 10^{9} \mathrm{CFU} \mathrm{g}^{-1}\right)$ and Propionibacterium acidipropionici $(20 \mathrm{x}$ $10^{9} \mathrm{CFU} \mathrm{\textrm {g } ^ { - 1 }}$ ). The inoculant dose and application method were as recommended by the manufacturer.

\section{Experimental design}

Silage was wrapped in PVC silos with a $0.1 \mathrm{~m}$ diameter and a $0.35 \mathrm{~m}$ height, with a volume of $2.75 \times 10^{-3} \mathrm{~m}^{3}$. A "Bunsen" type valve was attached to allow gases resulting from the fermentation process to escape freely. For homogeneity of density $\left(\mathrm{kg} \mathrm{m}^{-3}\right)$ across treatments, a standard sample without crude glycerin was weighed and set as the relative mass standard to other treatments in the silo. The average specific mass obtained was $981 \pm 14.63 \mathrm{~kg} \mathrm{~m}^{-3} \mathrm{NM}$, which was adopted as a standard for other treatments. Experimental silos were kept under cover, at room temperature, and opened at defined periods $(4,8,16,32$, and 64 days) after closing.

A factorial combination $(2 \times 4 \times 5)$ was used in a completely randomized design with three replicates per treatment as follows: with and without a bacterial inoculant, four crude glycerin levels $\left(0,75,150\right.$, and $\left.225 \mathrm{~g} \mathrm{~kg}^{-1} \mathrm{NM}\right)$, and five fermentation periods $(4,8,16,32$ and 64 days after ensilage).

\section{Variables measured}

At 64 days of fermentation, $500 \mathrm{~g}$ silage samples were collected for chemical composition analysis. These samples were oven-dried (55ㄷ for 72 hours) and milled to $1 \mathrm{~mm}$. Subsequently, dry matter (method number 934.01; AOAC, 1990) and mineral matter (MM) (method number 924.05; AOAC 1990) were determined. To define crude protein, total nitrogen was determined using the micro-Kjeldahl method, (method number 920.87; AOAC 1990), with a conversion factor of 6.25. The ether extract was determined gravimetrically after extraction with petroleum ether in a Soxhlet instrument (method number 920.85; AOAC 1990).

Neutral detergent fiber and acid detergent fiber analyses were performed according to Van Soest and Robertson (1985). Total carbohydrates (TC) and non-fibrous carbohydrates (NFC) were calculated according to the 
method described by Sniffen et al. (1992) and Hall (2000), respectively.

To quantify effluent produced, previously oven-dried sand ( $55^{\circ} \mathrm{C}$ for 24 hours) was stored in bags wrapped with fabricnon-fabric were added to the bottom of the silos. These bags were kept in an oven at $55{ }^{\circ} \mathrm{C}$ until the moment of ensiling.

To avoid errors during weighing after opening of the silos, the ensiled material was separated from the sandbags using a polyethylene screen. Effluent losses, gas losses, total dry matter losses, and total dry matter recovery were quantified using equations proposed by Jobim et al. (2007).

The silage samples from each fermentation period were used for the fermentation profile analysis, including $\mathrm{pH}$, titratable acidity, ammoniacal nitrogen, and microbial CFUs. The $\mathrm{pH}$ and TA were determined according to the technique described by Silva and Queiroz (2002). A pH meter table was used for all techniques. The evaluation of $\mathrm{NH}_{3}-\mathrm{N}$ was performed using the method proposed by Chaney and Marbach (1962). Silage samples were diluted in water and trichloroacetic acid (10\%) and analyzed using a spectrophotometer (Bioespectro SP-220) at a wavelength of $625 \mathrm{~nm}$.

The technique proposed by Cherney and Cherney (2003) was used for the quantification of microorganisms in the silage. Lactic acid bacteria quantification was performed by plating on MRS agar (Fluka Analytical) and incubating at $35^{\circ} \mathrm{C}$ for 72 hours. The enterobacteria population was determined by plating on Violet Red Bile Glucose Agar (Fluka Analytical) and incubating at $35^{\circ} \mathrm{C}$ for 48 hours. Molds and yeasts (fungi) were determined by plating on Potato Dextrose Agar (Acumedia) acidified with $10 \%$ tartaric acid after sterilization. These plates were incubated at $25^{\circ} \mathrm{C}$ for five days.

To a $25 \mathrm{~g}$ silage sample, $225 \mathrm{ml}$ of Ringer's solution was added and subsequently homogenized in an industrial blender for 1 minute to give a $10^{-1}$ dilution. Then, successive dilutions were performed aiming to obtain a range from $10^{-1}$ to $10^{-7}$. The cultivation was performed in sterile petri dishes. Plates containing $30-300 \mathrm{CFU}$ were considered amenable to counting.

In addition, the silage was air-exposed and subjected to aerobic stability analysis. In the final fermentation period $\left(64^{\text {th }}\right.$ day), after the silos were opened, approximately $1500 \mathrm{~g}$ of a composite sample of silage for each treatment was placed in an open aluminum tray and kept at room temperature (average $25^{\circ} \mathrm{C}$ ). The room temperature was measured utilizing four data loggers at random points. The silage temperature was measured every 15 minutes for 12 days with a data logger placed in the center of the silage mass. The aerobic stability was defined as the number of hours that the silage remained stable before the temperature rose $>2^{\circ} \mathrm{C}$ above room temperature (Moran et al., 1996).

\section{Statistical analysis}

The experiment was carried out in a completely randomized design with three replicates in a $2 \times 4 \times 5$ factorial scheme (with and without bacterial inoculant $\times 4$ levels of crude glycerin $\times 5$ fermentation periods). The silage chemical composition, losses, and aerobic stability were analyzed at 64 days, and the fermentation profile and microbial counts were analyzed over the fermentation period $(4,8,16,32$ and 64 days after ensilage). To determine the inoculant effect, means were estimated using LSMEANS, and the comparison was accomplished using the difference probability 'PDIFF' in the PROC MIXED procedure of SAS (version 9.1). A regression analysis using the PROC REG procedure of SAS (version 9.1) was used to evaluate the quantitative variables (levels of crude glycerin and fermentation period). In both analyses, 0.05 was considered the significance level for type I error.

\section{Conclusion}

The inclusion of a bacterial inoculant does not influence the chemical composition, losses, fermentative profile or aerobic stability of rehydrated corn grain silage.

The addition of crude glycerin inhibits microorganism growth, decreases dry matter recovery and aerobic stability of the silage, and its use is not recommended for rehydrated corn grain silage.

Rehydration with water is an alternative method for storage of corn grain silage.

\section{Acknowledgements}

The authors thank the CNPq for financing this project.

\section{References}

AOAC - Association of Official Analytical Chemists (1990) Official Methods of Analysis, $15^{\text {th }}$ edn. Arlington, VA. 1298p.

Arif, M, Abd El-Hack, M, Hayat, Z, Sohail, S, Saeed, M, Alagawany, $M$ (2017) The beneficial uses of glycerin as an alternative energy source in poultry diets World Poultry Sci J. 73(1):136-144.

Basso FC, Lara EC, Assis FB, Rabelo CHS, Morelli M, Reis RR (2012) Características da fermentação e estabilidade aeróbia de silagens de milho inoculadas com Bacillus subtilis. Rev Bras Saúde Prod Anim. 13:1009-1019.

Berg JM, Tymoczko JL, Stryer L (2002) Biochemistry, $5^{\text {th }}$ edn. London.

Carvalho VB, Leite RF, Almeida MTC, Paschoaloto JR, Carvalho EB, Lanna DPD, Perez HL, Van Cleef EHCB, Homem Junior AC, Ezequiel JMB (2015) Carcass characteristics and meat quality of lambs fed high concentrations of crude glycerin in low-starch diets. Meat Sci. 110:285-292.

Chaney AL, Marbach EP (1962) Modified reagents for determination of urea and ammonia. Clin Chem. 8:130132.

Cherney JH, Cherney DJR (2003) Assessing silage quality. In: Buxton DR, Muck RE, JH Harrison (ed) Silage science and technology, American Society of Agronomy, Crop Science Society of America, Soil Science of America, Madison, WI. p.141-198.

Danner H, Holzer, M, Mayrhuber E (2003) Acetic acid increases stability of silage under aerobic conditions. Appl Environ Microbiol. 69:562-567.

Dias AM, Ítavo LCV, Ítavo CCBF, Blan LR, Gomes ENO, Soares, CM, Leal ES, Nogueira E, Coelho EM (2014) Ureia e glicerina bruta como aditivos na ensilagem de cana-deaçúcar. Arq Bras Med Vet Zootec. 66:1874-1882. 
Ferraretto LF, Taysom K, Taysom DM, Shaver RD, Hoffman PC (2014) Relationships between dry matter content, ensiling, ammonia-nitrogen, and ruminal in vitro starch digestibility in high-moisture corn samples. J Dairy Sci. 97:3221-3227.

Gimenes ALG, Mizubuti IY, Moreira FB, Pereira ES, Ribeiro ELA, Mori RM (2006) Composição química e estabilidade aeróbia em silagens de milho preparadas com inoculantes bacteriano e/ou enzimático. Acta Sci Anim Sci. 28:153-158.

Gomes MAB, Moraes GV, Jobim CC, Santos TC, Oliveira TM, Rossi RM (2015) Nutritional composition and ruminal degradability of corn silage (Zea mays L.) with addition of glycerin in silage. Semina. 36:2079-2092.

Gonçalvez LU, Cerozi BS, Silva TSC, Zanon RB, Cyrino JEP (2015) Crude glycerin as dietary energy source for Nile tilapia. Aquaculture. 437:230-234.

Hall MB (2000) Calculation of non-structural carbohydrate content of feeds that contain non-protein nitrogen. University of Florida, Bulletin 339, 25-34.

Hoffman PC, Esser NM, Shaver RD, Coblentz WK, Scott MP, Bodnar AL, Schmidt RJ, Charley RC (2011) Influence of ensiling time and inoculation on alteration of the starchprotein matrix in high-moisture corn. J Dairy Sci. 94:24652474.

Hu S, Luo X, Wan C, Li Y (2012) Characterization of Crude Glycerol from Biodiesel Plants. J Agric Food Chem. 60:5915-5921.

Jobim CC, Nussio LG, Reis RA, Schmidt P (2007) Avanços metodológicos na avaliação da qualidade da forragem conservada. R Bras Zootec. 36:101-119.

Lara EC, Basso FC, Assis FB, Souza FA, Berchielli TT, Reis RA (2016) Changes in the nutritive value and aerobic stability of corn silages inoculated with Bacillus subtilis alone or combined with Lactobacillus plantarum. Anim Prod Sci. 56:1867-1874.

Kung Júnior L, Stokes MR, Lin CJ (2003) Silage additives. In: Buxton DR, Muck RE, JH Harrison (ed) Silage science and technology, American Society of Agronomy, Crop Science Society of America, Soil Science of America, Madison, WI. p. 305-360.

Martins AS, Oliveira JR, Lederer ML, Moletta JL, Galetto SL, Pedrosa VB (2014) Glycerol inclusion levels in corn and sunflower silages. Ciênc Agrotec. 38:497-505.

McAllister TA, Phillipe RC, Rode LM, Cheng KJ (1993) Effect of the protein matrix on the digestion of cereal grains by ruminal microorganisms. J Anim Sci. 71:205-212.

McDonald P, Henderson AR, Heron SJE (1991) The biochemistry of silage, $2^{\text {nd }}$ edn. Marlow, Bucks, UK.

Mohammadzadeh H, Khorvash M, Ghorbani GR (2014) Ensiling corn silage with different levels of a multi-species lactic acid bacteria inoculant. Anim Prod Sci. 54:165-171.

Moran JP, Weinberg Z, Ashbell Y, Hen Y, Owen T (1996) In: Jones DIH, Jones R, Dewhurst R, Merry R, Haigh PH (ed) Proceedings of the $\mathrm{XI}$ International silage conference, University of Wales, Aberystwyth, UK.

Muck RE (2004) Effects of corn silage inoculants on aerobic stability. American Society of Agricultural Engineers. 47:1011-1016.
Muck RE (2010) Silage microbiology and its control through additives R Bras Zootec. 39:183-191.

O'leary WM (1962) Department of Microbiology and Immunology. J Bacteriol. 84:967-972.

Oliveira JS, Antoniassi R, Freitas SC, Müller MD (2013) Composição química da glicerina produzida por usinas de biodiesel no Brasil e potencial de uso na alimentação animal. Cienc Rural. 43:509-512.

Oliveira L, Madrid J, Ramis G, Martínez S, Orengo J, Villodre C, Valera L, López MJ, Palláres FJ, Quereda JJ, Mendonça L, Hernández F. (2014) Adding crude glycerin to nursery pig diet: Effect on nutrient digestibility, metabolic status, intestinal morphology and intestinal cytokine expression. Livest Sci. 167:227-235.

Pahlow G, Muck RE, Driehuis F, Oude Elferink SJWH, Spoelstra SF (2003) Microbiology of ensiling. In: Buxton DR, Muck RE, JH Harrison (ed) Silage science and technology, American Society of Agronomy, Crop Science Society of America, Soil Science of America, Madison, WI. p. 31-94.

Santos AO, Ávila CLS, Schwan RF (2013) Selection of tropical lactic acid bacteria for enhancing the quality of maize silage. J Dairy Sci. 96:7777-7789.

Silva DJ, Queiroz AC (2002) Análises de alimentos: métodos químicos e biológicos, $3^{\text {nd }}$ edn, Federal Univerity of Viçosa, Viçosa, MG.

Simas DLR, Silva PN, Fernandes VC, Campos RC, Antoniassi R, Freitas SC, Oliveria JC (2010) Composição de amostras de glicerina bruta provenientes da síntese de biodiesel. $33^{\text {th }}$ Reunião Anual da Sociedade Brasileira de Química, Águas de Lindóia, GO.

Sniffen CJ, O'Connor JD, Van Soest PJ, Fox DG, Russell JB (1992) A net carbohydrate and protein system for evaluating cattle diets. II. Carbohydrate and protein availability. J Anim Sci. 70:3562-3577.

Thompson JC, He BB (2006) Characterization of crude glycerol from biodiesel production from multiple feedstocks. Appl Eng Agric. 22:261-265.

Van Cleef EHCB, Silva Filho JC, Neiva Júnior AP, Pardo RMP, Rêgo AC, Gonçalves JS (2012) Chemical composition and fermentation characteristics of elephant grass silage with biodiesel industry co-products. Ciênc Rural. 42:718-723.

Van Cleef EHCB, Ezequiel, JMB, D'Aurea, AP, Fávaro, VR, Sancanari, JBD (2014) Crude glycerin in diets for feedlot Nellore cattle. R Bras Zootec. 43(2): 86-91.

Van Soest PJ, Robertson JB (1985) Analysis of forages and fibrous foods. Cornell University Press: Ithaca, New York.

Weinberg ZG; Muck RE (1996) New trends and opportunities in the development and use of inoculants for silage. FEMS Microbiology Rev. 19(1):53-68

Woolford MK (1984) The silage fermentation. Marcel Dekker Inc. New York.

Zopollatto M, Daniel JLP, Nussio LG (2009) Aditivos microbiológicos em silagens no Brasil: revisão dos aspectos da ensilagem e do desempenho de animais. R Bras Zootec. 38:170-189. 